\title{
Criteria of choosing building structures for rooftop boiler rooms
}

\author{
Artyom Plotnikov ${ }^{1, *}$, and Tatiana Zhilina ${ }^{1}$ \\ ${ }^{1}$ Tyumen Industrial University, 625000 Tyumen, Russia
}

\begin{abstract}
The paper investigates parameters of noise and vibration distribution in the territory of residential area depending on the structural materials and power of independent heat supply systems. Rooftop boiler rooms are decentralized heat supply systems in buildings.Today, residential areas are strongly affected by noise and vibrations. Adverse effects are isolated by buildings materials, protective shields and floating floors. Rooftop boiler rooms located in Tyumen city were investigated within this research. Structures of rooftop boiler rooms were analyzed. Acoustic analysis results and the parameters of equivalent continuous sound level are presented. An option for improvement of rooftop boiler rooms structures is suggested. Comparison of capital investments in construction and installation activities is carried out. Conclusion on capital investments required for noise protection is made.
\end{abstract}

\section{Introduction}

Development of cities and residential areas leads to growth of engineering networks in order to provide comfortable living conditions in new districts. In particular, the issue of providing heating to the Russian cities is connected with certain climate conditions and long heating period [1] and is one of the top priorities of the government [2].

The existing techniques of providing heating are represented by two standard solutions [3]:

- centralized heating supply systems, i.e. heating supply of a big residential area of an industrial complex with a common heat network of one or several heating energy sources;

- decentralized heating supply systems (independent), i.e. heating supply of one consumer from one heating energy source.

This paper investigated the parameters of noise and vibration distribution [4] in the territory of residential area $[5,6]$ with regard to structural building materials and power of decentralized (independent) heating supply systems. The purpose of the study is to substantiate the minimum number of reasonable criteria for choosing structures for construction of rooftop boiler rooms.

Rooftop boiler rooms are decentralized heating supply systems in buildings. One of the major issues of independent heating sources organization is the proximity of technical equipment which uses natural gas [7] in devices that do not belong to the category of

\footnotetext{
${ }^{*}$ Corresponding author: stereo-twist $@$,yandex.ru
} 
hazardous production facilities of high hazard [8] to the residential premises. Side effects of such proximity are noise and vibrations, which inherently go along with each other and affect the residential area. The issue of proximity of people, technical equipment and engineering networks is highly relevant for urban planning of new residential districts and infill development [9-13].

\section{Materials and Methods}

The methods of noise and vibration control that are used in construction and energy production industries shall account both cost and efficiency. People are isolated from adverse effects by means of building materials, protective shields and floating floors, i.e. by everything that absorbs and reflects noise and vibration.

\section{Experiment}

Rooftop boiler rooms located in the city of Tyumen (Russia), in "Mys" residential district under construction (planning area No. 14), were selected for experimental research within the study. Full-scale measurements [14] were carried out by using ASSISTENT TOTAL sound level meter.

Structures of several rooftop oiler rooms were analyzed. Then, the analysis of structural properties of sound absorption $[15,16]$ and full-scale measurements were performed. The following conclusion was made based on the results: structures are selected with the account of minimum cost and, consequently, have minimum protective effect. The used structural materials of walls, foundations and roof are presented in Figure 1.

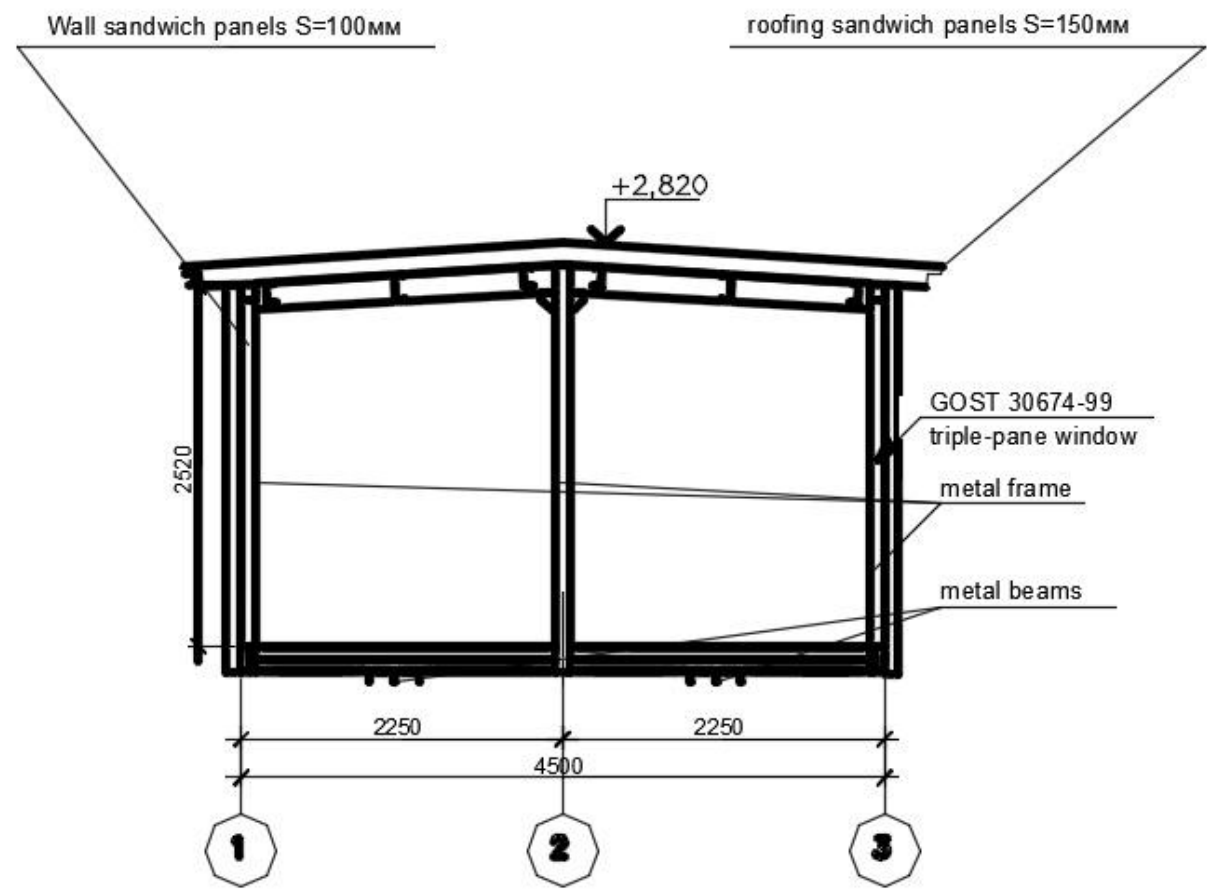

Fig. 1. Structural elements of rooftop boiler rooms. 
Boiler rooms with the power of 1.0; 1.5; $2.0 \mathrm{MW}$ were accepted for analysis.

After conducting acoustic analysis of boiler rooms [15, 16, 17] and full-scale measurements of sound level outside the boiler rooms the following results were obtained (Table 1).

Table 1. Parameters of equivalent continuous sound level in the existing boiler rooms.

\begin{tabular}{|c|c|c|c|c|c|c|c|c|c|}
\hline \multirow{2}{*}{$\begin{array}{c}\text { Capacity, } \\
\text { MW }\end{array}$} & \multicolumn{9}{|c|}{ Values of the analyzed parameters for octave band center frequencies in a } \\
& \multicolumn{7}{|c|}{$\begin{array}{c}\text { Equivalent } \\
\text { continuous room [18, 19], Hz } \\
\text { sound level, } \\
\text { dB }\end{array}$} \\
\cline { 2 - 12 } & 63 & 125 & 250 & 500 & 1000 & 2000 & 4000 & 8000 & \\
\hline 1.0 & 31.5 & 37.7 & 45.1 & 41.4 & 38.0 & 37.0 & 33.0 & 34.2 & 47 \\
\hline 1.5 & 34.3 & 41.1 & 53.1 & 45.4 & 43.0 & 32.0 & 38.0 & 38.2 & 52 \\
\hline 2.0 & 37.3 & 43.2 & 53.1 & 45.4 & 43.0 & 42.0 & 38.0 & 38.2 & 56 \\
\hline $\begin{array}{c}\text { Standard } \\
\text { parameters [20] }\end{array}$ & 63 & 52 & 45 & 39 & 35 & 32 & 30 & 28 & 40 \\
\hline
\end{tabular}

Data in Table 1 demonstrate the actual parameters in a boiler room for the values of 250-8000 Hz are higher than octave band center frequencies. This interval includes spectra of human hearing.

The following improvements of the boiler rooms structures are suggested: increase thickness of roof elements and wall panels and replace the type of glazing by installing triple-pane glass.

Modified boiler room structures are presented in Figure 2.

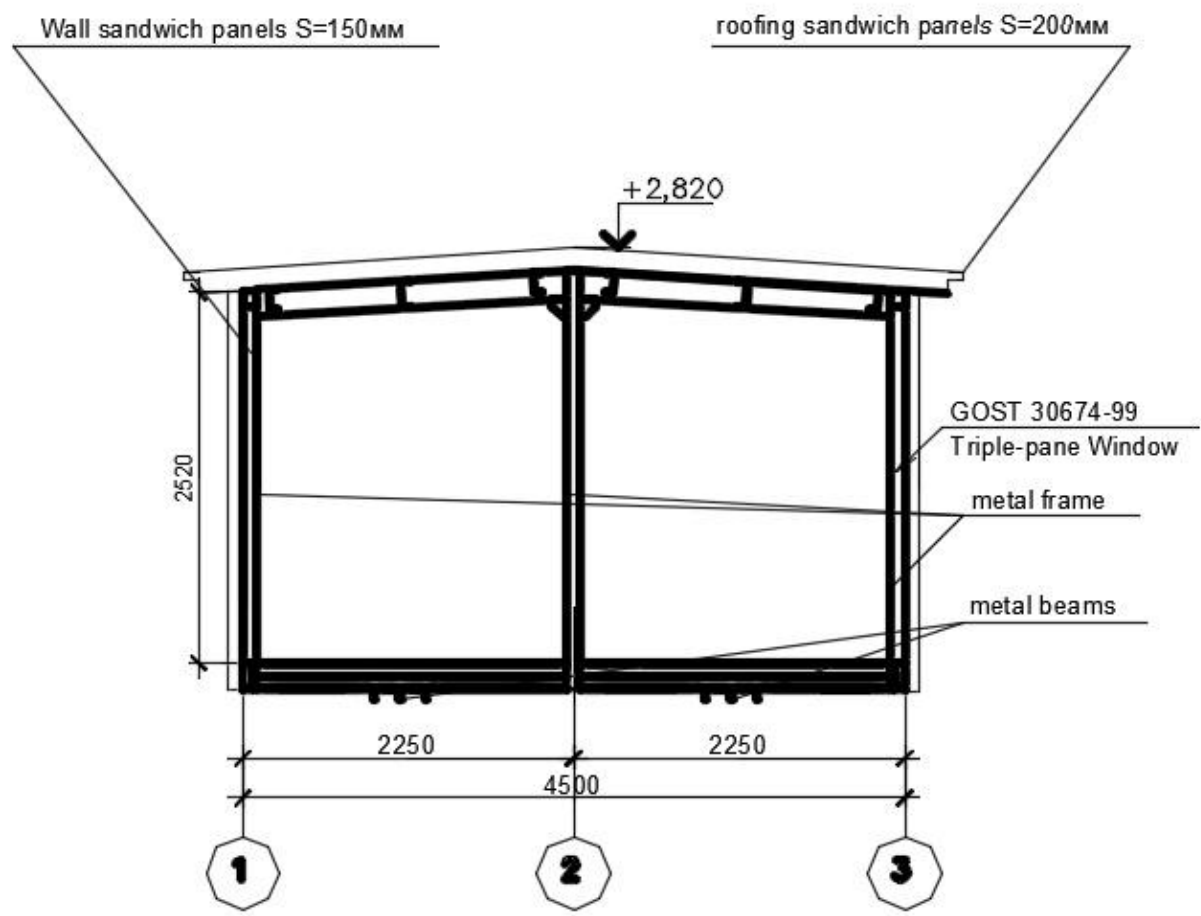

Fig. 2. Modified structural elements of rooftop boiler rooms. 
Repeated acoustic analysis and full-scale measurements were performed after modifying structures and increasing the level of noise protection. The result sound level parameters are given in Table 2.

Table 2. Parameters of equivalent continuous sound level in the improved boiler rooms.

\begin{tabular}{|c|c|c|c|c|c|c|c|c|c|}
\hline \multirow{2}{*}{$\begin{array}{l}\text { Capacity, } \\
\text { MW }\end{array}$} & \multicolumn{8}{|c|}{$\begin{array}{l}\text { Values of the analyzed parameters for octave band center frequenciesin a } \\
\text { boiler room }[18,19], \mathrm{Hz}\end{array}$} & \multirow{2}{*}{$\begin{array}{c}\text { Equivalent } \\
\text { continuous } \\
\text { sound level, } \\
\text { dB }\end{array}$} \\
\hline & 63 & 125 & 250 & 500 & 1000 & 2000 & 4000 & 8000 & \\
\hline 1.0 & 31.5 & 36.7 & 41.1 & 40.4 & 36.0 & 29.0 & 31.0 & 27.2 & 37 \\
\hline 1.5 & 34.3 & 39.1 & 43.1 & 41.4 & 39.0 & 28.0 & 33.0 & 29.2 & 44 \\
\hline 2.0 & 37.3 & 40.2 & 43.1 & 41.4 & 39.0 & 32.0 & 33.0 & 29.2 & 47 \\
\hline $\begin{array}{c}\text { Standard } \\
\text { parameters [20] }\end{array}$ & 63 & 52 & 45 & 39 & 35 & 32 & 30 & 28 & 40 \\
\hline \multicolumn{10}{|c|}{ Sound level variation before and after improvement } \\
\hline 1.0 & 0 & -1 & -4 & -1 & -2 & -8 & -2 & -5 & -10 \\
\hline 1.5 & 0 & -2 & -10 & -4 & -4 & -4 & -5 & -9 & -8 \\
\hline 2.0 & 0 & -3 & -10 & -4 & -4 & -10 & -5 & -9 & -9 \\
\hline
\end{tabular}

Improvement of boiler room structures results in decrease of acoustic load parameters, including spectra of human hearing. The parameters of acoustic load variations are given in the table.

\section{Results}

Envelope structures of a boiler room were modified to improve noise protection parameters. Repeated analysis of a boiler room sound absorption was performed with the account of all construction requirements [3].

Figure 3 demonstrates the comparison of capital investments in construction and installation of an independent rooftop heating supply source.

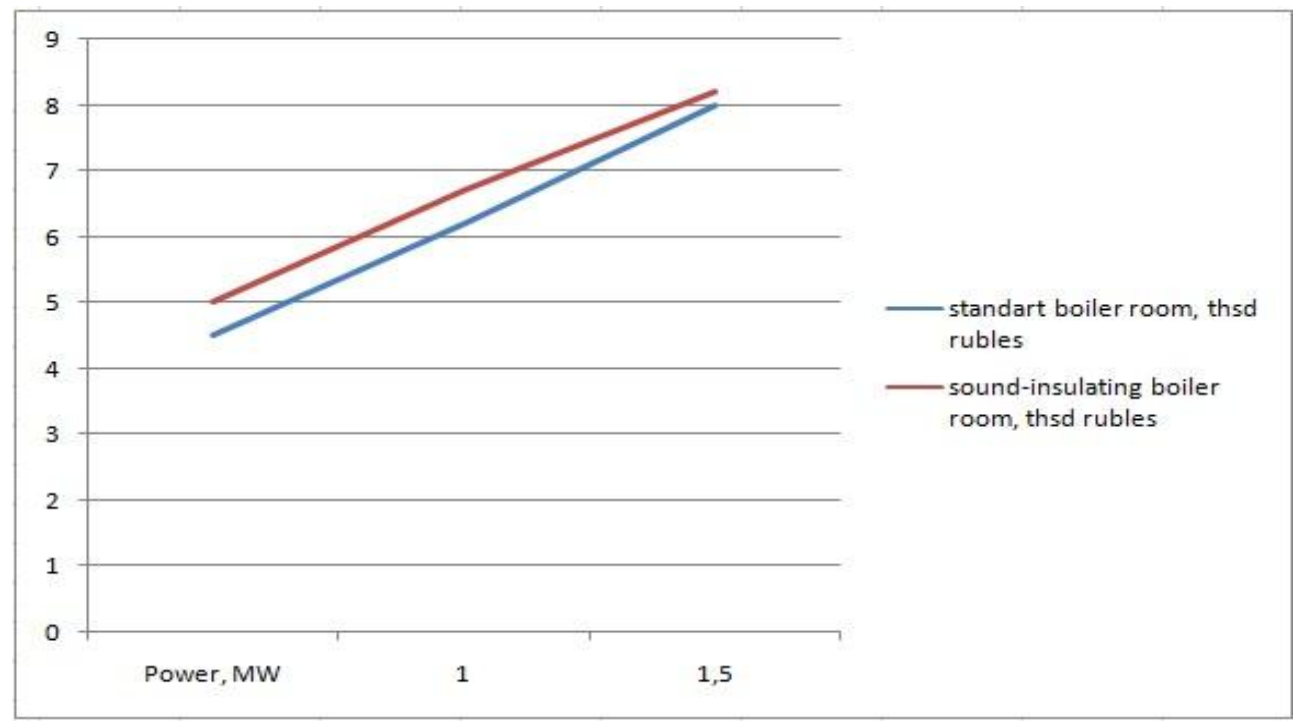

Fig. 3. Comparison of capital investment. 
Production plant prices were used to perform economic comparison of the boiler room cubicle cost. The results of calculations are presented in Table 3.

Table 3. Cubicle cost before and after improvement

\begin{tabular}{|c|c|c|}
\hline \multirow{2}{*}{$\begin{array}{c}\text { Power capacity, } \\
\text { MW }\end{array}$} & $\begin{array}{c}\text { Standard boiler room cubicle } \\
\text { (Fig.1) }\end{array}$ & $\begin{array}{c}\text { Sound-insulating boiler room } \\
\text { cubicle (Fig.1) }\end{array}$ \\
\cline { 2 - 3 } & price, thousand rubles & price, thousand rubles \\
\hline 1.0 & 4.5 & 5.0 \\
\hline 1.5 & 6.2 & 6.7 \\
\hline 2.0 & 8 & 8.3 \\
\hline
\end{tabular}

Data from Table 3 demonstrate that the increase of cubicle cost is between 4 and $11 \%$ depending on the power capacity of the boiler room.

\section{Conclusion}

According to the full-scale measurement and analysis results, one can conclude that rooftop boiler rooms are a bigger source of noise and vibration. The reduced noise level of rooftop boiler rooms increases the level of living comfort and the improved structures provide higher level of noise protection of boiler rooms without considerable increase of capital investments. Further research in the field will be focused on development of recommendations to production plants on improvement of structures of boiler rooms cubicles.

\section{References}

1. SP 131.13330.2012. Building climatology. Revised edition of SNIP 23-01-99* (2012) (in Russian)

2. A.S. Plotnikov, T.S. Zhilina, Nauchnoe obozrenie. Tehnicheskie nauki [Scientific review. Engineering sciences] 6, 84 (2016) (in Russian)

3. SP 89.13330.2016. Boiler installations. Revised edition of SNIP II-35-76 (2016) (in Russian)

4. W.J. Bottega, Engineering Vibrations (Taylor \& Francis Group, 2015)

5. V.B. Tupov, Proceedings of the V All-Russian scientific conference "Protection against Increased Noise and Vibration", 57 (2015) (in Russian)

6. L. David; G. Benoît, INTER-NOISE and NOISE-CON Congress and Conference Proceedings, InterNoise 16, 1149-1158 (2016)

7. N.K. Kiryushina, V.N. Stepanov, Proceedings of the V All-Russian scientific conference "Protection against Increased Noise and Vibration", 25 (2015) (in Russian)

8. GOST 5542-2014. Natural gas for industrial and household purpose (2015) (in Russian)

9. A.Preis, H.Honorata, S.Malina, K.Jedrzej, Noise Control Engineering Journal 64, 1 (2016)

10. M.V.M.Oliveira Filho, P.H.T.Zannin, Performance of Sound Insulation in Buildings 21, 3 (2016)

11. B. Fernando, Z.P.H. Trombetta, Noise Control Engineering Journal 63, 1 (2015)

12. M.Ermann, J.Wiley, Architectural Acoustics (John Wiley \& Sons Inc, 2017)

13. Brown, Alan Lex, INTER-NOISE and NOISE-CON Congress and Conference Proceedings, InterNoise16, 550-556 (2016) 
14. GOST 23337-2014. Noise. Methods of noise measurement in residential areas and in the rooms of residential, public and community buildings (2015) (in Russian)

15. Recommendations for the acoustic calculation of boiler houses. Series Ж3-172 (Moscow, 1984) (in Russian)

16. GOST R EN 12354-5-2012. Building acoustics. Calculation methods for building acoustic properties on the base of their element's properties. Part 5. Engineering equipment noise (2014) (in Russian)

17. A.A. Ivanovich, A.V. Bacunova, I.L. Shubin, Vestnik of TSUAB 6, 71 (2015) (in Russian)

18. G.L. Osipov, V.N. Bobylev, Zvukoizoljacija i zvukopogloshhenie [Acoustic isolation and sound absorbing] (Astrel, Moscow, 2004) (in Russian)

19. A.I. Antonov, A.V. Batsunova, I.L. Shubin, Privolzhsky Scientific Journal 3, 85 (2015) (in Russian)

20. SP 51.13330.2011. Noise protection. Revised edition of SNIP 23-03-2003 (2011) (in Russian) 